Original Research

\title{
Effects of Irrigation and Nitrogen Management on the Growth and Nitrogen Concentration of Paddy Soil and Rice Plants
}

\author{
Wenlu Guan', Xiaohou Shao ${ }^{1 *}$, Yuanyuan $\mathbf{L i}^{2}$ \\ ${ }^{1}$ College of Agricultural Engineering, Hohai University, China \\ ${ }^{2}$ North China University of Water Resources and Electric Power, China
}

Received: 22 January 2020

Accepted: 20 April 2020

\begin{abstract}
Traditional fertilization and irrigation methods have resulted in low nitrogen $(\mathrm{N})$ use efficiency and large $\mathrm{N}$ loss. Reducing $\mathrm{N}$ fertilizer input is a necessary condition for environmental protection. We investigated the effects of different irrigation and fertilization on rice growth and soil $\mathrm{N}$ dynamics. Results showed that the growth of rice under two irrigation regimes was not significant, while the effect of fertilization on growth was significant. The combined application of organic and inorganic fertilizers was beneficial to the conversion of $\mathrm{N}$ in the soil, and reduced the $\mathrm{N}$ concentration in the paddy soil, as well as reduced the risk of $\mathrm{N}$ loss. Compared to the unfertilized control, the application of combined organic and inorganic fertilizers, as well as a controlled irrigation method, promoted $\mathrm{N}$ use efficiency, improved rice production, and decreased $\mathrm{N}$ pollution to the environment. Taking the indices of the growth of rice, nitrogen accumulation, nitrogen use efficiency into account, the combination of organic and inorganic fertilizer applications and controlled irrigation are recommended to be a proper irrigation and $\mathrm{N}$ application strategy for paddy soil and rice plants.
\end{abstract}

Keywords: irrigation regimes, fertilizer regimes, soil nitrogen, nitrogen accumulation, nitrogen use efficiency

\section{Introduction}

Rice is an important staple food worldwide. With global population growth, farmers need to produce more and higher quality rice to meet people's demands. However, the yield of rice is lower than its production potential, which may be due to inappropriate use of chemical fertilizers. Nitrogen $(\mathrm{N})$ is still one of the

*e-mail: shaoxiaohou@163.com main factors that restrict agricultural production. The availability of $\mathrm{N}$ positively influences crop the growth, $\mathrm{N}$ utilization and yield [1]. With the excessive use of chemical fertilizers, more and more serious consequences have been caused, such as nutrient imbalance in the soil, seriously water loss and soil erosion, loss of nitrogen fertilizer and [2].

As the largest nitrogenous fertilizer-consuming country, the utilization efficiency of $\mathrm{N}$ fertilizer in China is very low due to surface run-off and leaching. Researchers have suggested that the $\mathrm{N}$ fertilizer 
utilization rate of the main grain crops range from 10.8 to $40.5 \%$, with an average of $27.5 \%$, which is far below the international level of $40-60 \%$ [3]. The serious loss of soil $\mathrm{N}$ and low utilization rates of $\mathrm{N}$ fertilizer are serious problems that restrict the development of high-yield, high-efficiency, and high-quality agriculture in China [3]. Instead of conventional application of inorganic fertilizers in agriculture, several studies have recently investigated the combination of inorganic and organic fertilizers as a means of preventing environmental degradation caused by the overuse of fertilizers. Research has shown that combining the application of organic and inorganic fertilizers does only improved the utilization rate of nutrients [3-5] and characteristics of the soil $\mathrm{N}$ supply but also, it promoted $\mathrm{N}$, phosphorus $(\mathrm{P})$, and potassium $(\mathrm{K})$ nutrient uptake of rice plants when compared to single applications of chemical fertilizers [6-8]. The combined application of organic and inorganic fertilizers has proven to be a sound method in soil fertility management in many countries [9-11]. For example, grain yield significantly increased by combining inorganic fertilization and irrigation management with crop cultivation technologies in the Taihu Lake region [10]. In addition, the use of organic fertilizer may significantly reduce nutrient-leaching losses and groundwater pollution, thereby protecting the ecological environment $[12,13]$.

Most studies in recent years have focused on $\mathrm{N}$ fertilizer use efficiency in relation to rice growth and yield, while research on the combined application of organic and inorganic fertilizers has mostly focused on the impact of submerged irrigation for rice. With the popularization of water-saving irrigation techniques, controlled irrigation has been widely used in paddy fields in southern China. However, little research has been conducted on the effects of different irrigation and fertilization conditions on the environmental benefits and grain yield. And there are very few studies on the impact on rice growth and nitrogen use efficiency with the combined application of organic and inorganic fertilizers under controlled irrigation conditions. Thus, in this study, we examined the dynamic changes of soil $\mathrm{N}$ concentration and the growth and yield of rice under different irrigation and fertilization conditions, including the mechanism of crop $\mathrm{N}$ utilization. The aim of this study was to provide a theoretical basis for the efficient utilization of $\mathrm{N}$ fertilizers and the reduction of environmental pollution in agricultural production systems [14].

\section{Experimental}

\section{Site and Conditions}

The experiment was conducted during the 2015-2016 rice-growing season at the Vegetables and Flowers Institute of Jiangning $\left(32^{\circ} 13^{\prime} \mathrm{N}, 119^{\circ} 04^{\prime} \mathrm{E}\right)$, Nanjing, China. The experimental site is located in a subtropical humid region, with an average annual rainfall of $1106.5 \mathrm{~mm}$, which falls mostly in the rainy season from the end of June to the middle of September. The average annual evaporation was $1472.5 \mathrm{~mm}$, and the average annual sunshine was $2017.2 \mathrm{~h}$. In addition, the average annual temperature was $15.7^{\circ} \mathrm{C}$, the maximum average humidity was $81 \%$, and the average wind speed was $19.8 \mathrm{~m} / \mathrm{s}$.

\section{Experimental Design}

We used a split-plot design to study the influence of fertilizer and irrigation regimes on soil physicochemical properties and paddy rice yield. There were two irrigation regimes (conventional irrigation $(\mathrm{C} 1)$ and controlled irrigation (C2)), and three fertilizer regimes: inorganic fertilizer alone (S1), organic and inorganic fertilizer (S2), and unfertilized control (S3). Rice (cv. Kaohsiung, Taiwan 139) plants were transplanted with a density between 703,500 and 825,000 seedlings per hectare. The sub-plots were $10 \mathrm{~m}^{2}$, and each treatment was replicated three times. Each plot had isolated irrigation and drainage ditches to prevent the spread of water and fertilizers between plots.

Controlled irrigation technology is a type of watersaving irrigation technology; it allows water to be delivered to crops based on demand during different stages of growth thereby saving water while benefiting crops. It avoids the past practice of continuously flooding rice fields; instead, in the controlled irrigation treatment, maximum soil water content is limited to $70 \%$ of saturation. The inorganic fertilizer treatment was $\mathrm{N}: \mathrm{P}_{2} \mathrm{O}_{5}: \mathrm{K}_{2} \mathrm{O}=15: 13: 17$. It was split-applied at transplanting and approximately 30 days after transplanting (i.e., tillering fertilizer) to give a final level of $\mathrm{N}$ in soil. The mixed fertilizer consisted of the inorganic formulation described above plus chicken manure $(1.8 \% \mathrm{~N} ; 28 \%$ organic matter). The two fertilizer sources were mixed in a ratio of $6: 4$ to give $\mathrm{N}$ in soil such that the levels of $\mathrm{P}$ and $\mathrm{K}$ in treatments were consistent. The water and fertilizer treatment designs during the different growth stages of the paddy rice are shown in Table 1.

\section{Measurements and Indicators}

Three representative rice plants were sampled every seven days in each plot to determine their plant heights. The plant heights were measured as the average height of plants in the three heights. A leaf area meter was used to measure the green leaf area at the full heading stage. The leaf area index (LAI) was calculated as follows:

$$
\mathrm{LAI}=\mathrm{A}_{\mathrm{s}} / \mathrm{S}
$$

...where $\mathrm{A}_{\mathrm{s}}$ was the leaf area, and $\mathrm{S}$ was the ground area. LAI is an important agronomic parameter that reflects potential crop growth and can be used when predicting 
Table 1 . The irrigation and fertilizer regimes for different treatments.

\begin{tabular}{|c|c|c|}
\hline Treatment & Irrigation & Fertilizer \\
\hline $\mathrm{C} 1 \mathrm{~S} 1$ & Conventional irrigation & Inorganic fertilizer \\
\hline $\mathrm{C} 1 \mathrm{~S} 2$ & Conventional irrigation & Organic and inorganic fertilizer \\
\hline $\mathrm{C} 1 \mathrm{~S} 3$ & Conventional irrigation & Unfertilized control \\
\hline $\mathrm{C} 2 \mathrm{~S} 1$ & Controlled irrigation & Inorganic fertilizer \\
\hline $\mathrm{C} 2 \mathrm{~S} 2$ & Controlled irrigation & Organic and inorganic fertilizer \\
\hline $\mathrm{C} 2 \mathrm{~S} 3$ & Controlled irrigation & Unfertilized control \\
\hline
\end{tabular}

crop yield [15]. In fact, the relationship between LAI and rice yield was studied by Zhu et al. [16], who determined that a LAI that was either too big or too small would affect rice growth.

The soil samples were collected using the five-point method from the $0-20 \mathrm{~cm}$ and $20-40 \mathrm{~cm}$ soil layers. After air-drying and crushing, the soil was passed through a 100 -mesh sieve. The total $\mathrm{N}$ content was measured using the semi-micro Macro Kjeldahl method, nitrate $\mathrm{N}$ was measured with the phenol-disulfonic acid method, and ammonium $\mathrm{N}$ was measured with a $\mathrm{KCl}$ solution extraction-indophenol blue spectrophotometry method. The specific methods used in this study were followed methods described by Borgognone et al. [17]; Bao et al. [18].

Dry matter accumulation was measured using the drying and weighing method [19]. Samples were separated into leaf, stem, and panicle, and then dried to a constant weight in an oven at $75^{\circ} \mathrm{C}$.

The quantitative indicators of nitrogen use efficiency include agronomy efficiency of nitrogen $\left(\mathrm{AE}_{\mathrm{N}}\right)$, physiological efficiency of nitrogen $\left(\mathrm{PE}_{\mathrm{N}}\right)$, surface appearance efficiency of nitrogen $\left(\mathrm{SE}_{\mathrm{N}}\right)$, and efficiency of nitrogen $\left(E_{N}\right)$. Nitrogen fertilizer use efficiency indices were calculated as follows:

$$
\begin{gathered}
\mathrm{AE}_{\mathrm{N}}=\left(\mathrm{Y}_{\mathrm{N}}-\mathrm{Y}_{0}\right) / \mathrm{F}_{\mathrm{N}}, \\
\mathrm{PE}_{\mathrm{N}}=\left(\mathrm{Y}_{\mathrm{N}}-\mathrm{Y}_{0}\right) /\left(\mathrm{U}_{\mathrm{N}}-\mathrm{U}_{0}\right), \\
\mathrm{SE}_{\mathrm{N}}=\left(\mathrm{U}_{\mathrm{N}}-\mathrm{U}_{0}\right) / \mathrm{F}_{\mathrm{N}}, \\
\mathrm{E}_{\mathrm{N}}=\mathrm{Y}_{\mathrm{N}} / \mathrm{U}_{\mathrm{N}},
\end{gathered}
$$

...where $\mathrm{F}_{\mathrm{N}}$ is the amount of $\mathrm{N}$ fertilizer applied, $\mathrm{Y}_{\mathrm{N}}$ is the grain yield in the plot that received $\mathrm{N}$ fertilizer, $\mathrm{Y}_{0}$ is the grain yield in the non-fertilized control plot, $U_{N}$ is the total $\mathrm{N}$ accumulation in plants in the plot that received $\mathrm{N}$ fertilizer, and $\mathrm{U}_{0}$ is the total $\mathrm{N}$ accumulation in plants in the non-fertilized control plot.

The yield components for panicle number, kernel weight, and kernel number per panicle were determined in a sample area of $1 \mathrm{~m}^{-2}$. Theoretical rice yield was calculated using formula (6), while the actual yield was recorded from each experimental plot.

$$
\mathrm{Y}=\mathrm{P} \times \mathrm{TGP} \times \mathrm{TGW} \times 10^{-2}
$$

...where $Y$ is theoretical yield, $\mathrm{kg} \cdot \mathrm{hm}^{-2} ; P$ is productive panicles, $\mathrm{m}^{-2}$; $T G P$ is total grains per panicle; $T G W$ is thousand grain weight, $\mathrm{g}$.

\section{Statistical Analysis}

All data were statistically analyzed using analysis of variance (ANOVA) with SPSS statistical software. The mean differences among treatments were analyzed using Duncan's Multiple Range Test. The homogeneity of variance was tested before the ANOVA analysis. Graphical analyses were done using Excel software [20].

\section{Results}

\section{Plant Growth Metrics}

\section{Plant Height and Leaf Area Index}

Plant height revealed the overall vegetative growth of the crop in response to various management practices. In general, the rice plants grew slowly and exhibited uniformity at the beginning of the growth period, but started showing differences at the tillering stage (Fig. 1). In the jointing-booting and heading-flowering

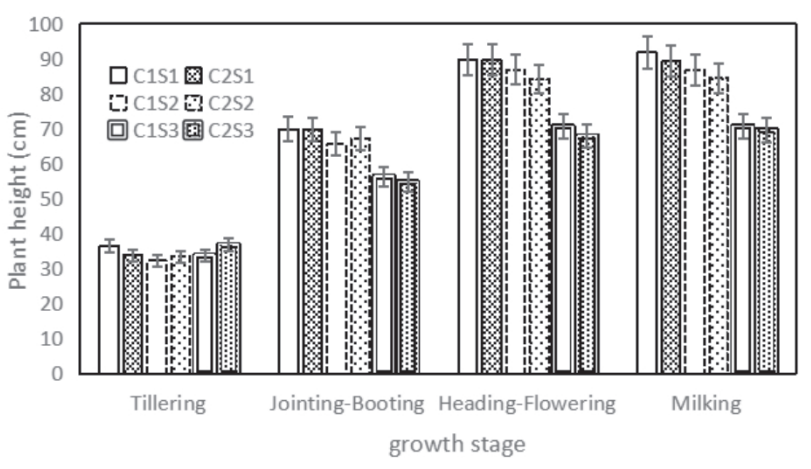

Fig. 1. Plant height of rice subjected to different irrigation and fertilization treatments. 


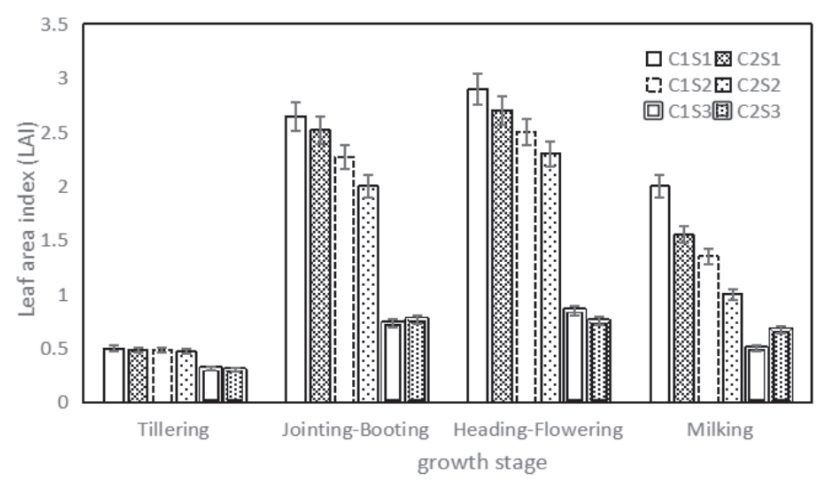

Fig. 2. Leaf area index of rice plants in various growth stages under different treatments.

stages, the differences in plant height were significant $(\mathrm{P} \leq 0.05)$, while in the milking stage, the difference was not obvious relatively. Beginning in the tillering stage, under the same fertilizer application amount, in comparison with the conventional irrigation treatment, the plant height was slightly lower in the controlled irrigation treatment conditions. Under the same irrigation application amount, the fertilizer treatments had a significant effect $(\mathrm{P} \leq 0.05)$ on plant growth during all the different growth stages.

Leaf area index (LAI) was a good indicator of the rice population growth. As shown in Fig. 2, the LAI of all the treatments showed variation, first increasing and then decreasing over the course of the whole growth period. At the beginning of tillering, the rice grew rapidly, establishing a strong root system that transportation a high water and fertilizer uptake ability, and the LAI increased rapidly.[21] LAI reached its maximum in the heading-flowering stage, after which there was leaf senescence and the LAI decreased rapidly. Under the same fertilizer application amount, the peak value for C1S2 and C2S2 were 2.7 and 2.9. while under the same irrigation conditions, the peak value for $\mathrm{C} 2 \mathrm{~S} 1, \mathrm{C} 2 \mathrm{~S} 2$ and $\mathrm{C} 2 \mathrm{~S} 3$ were $2.5,2.9,0.77$. The results of this study showed that the effect of irrigation mode on the LAI was not obvious, and there was a significant effect among the effect of fertilization mode on the LAI.

\section{Dry Matter Accumulation}

Dry matter accumulation increased significantly with the application of organic and inorganic fertilizer to rice under all growth stages (Fig. 3). In general, dry matter accumulation increased at a slow rate for the 30 days following transplanting, and then increased at a faster rate up until harvest. The proportion of total dry matter that was panicle dry matter in the the treatment $\mathrm{C} 1 \mathrm{~S} 2$ and the treatment $\mathrm{C} 2 \mathrm{~S} 2$ accounted for $49.5 \%$ and $42.2 \%$, respectively, under the organic and inorganic fertilizers. The treatment $\mathrm{C} 2 \mathrm{~S} 2$ did not differ from the treatment $\mathrm{C} 1 \mathrm{~S} 2$ in the peak amount of dry matter, although the treatment $\mathrm{C} 2 \mathrm{~S} 2$ had a numerically

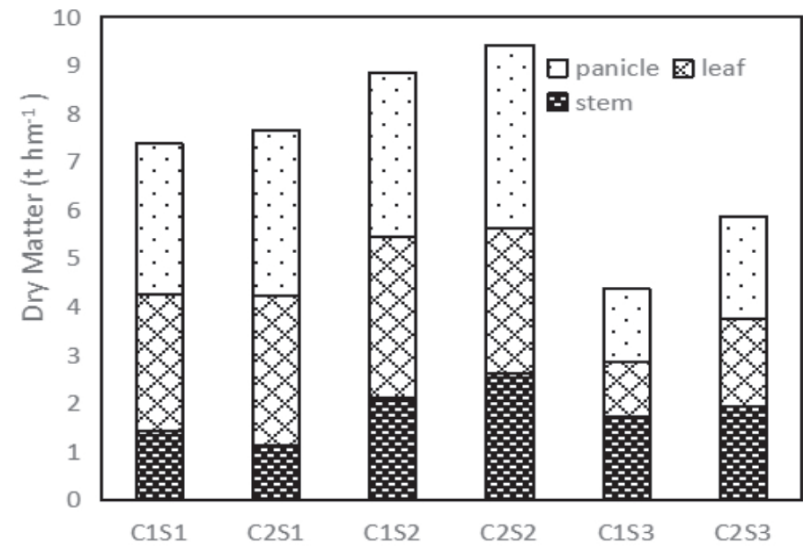

Fig. 3. Accumulated dry matter of rice (by panicle, leaf and stem) subjected to different fertilizer and irrigation treatments.

higher panicle dry matter than the treatment C1S2. Dry matter weights differed significantly among the different fertilization treatments within the controlled irrigation treatment, with higher weights correlated with the organic and inorganic fertilizers (C2S2) compared to the plants receiving inorganic fertilizer alone (C2S1) (Fig. 3). The treatments $\mathrm{C} 2 \mathrm{~S} 1$ and $\mathrm{C} 2 \mathrm{~S} 2$ had significantly increased dry matter as compared to the treatment $\mathrm{C} 2 \mathrm{~S} 3$ by $26.3 \%$ and $60.4 \%$, respectively.

At harvest time, on the condition of same fertilization, the total dry matter accumulation in the conventional irrigation treatment (C1S2) was slightly lower than that of the controlled irrigation treatment (C2S2), and under the same irrigation, the treatments that used organic and inorganic fertilizers showed a greater dry matter than those that used inorganic fertilizer alone. The treatment $\mathrm{C} 2 \mathrm{~S} 2$ achieved the highest dry matter in all treatments.

\section{Yield}

The yield of rice is composed of three components: productive panicles per $\mathrm{m}^{2}$, total grains per panicle, the thousand-grain weight. We found that effective panicles, total grains per panicle, and thousandgrain weight were all significantly increased with controlled irrigation and organic fertilizer additions (Table 2). Under the combined application of organic and inorganic fertilizer, the number of effective panicles, the thousand-grain weight and the grain yield in the treatment $\mathrm{C} 2 \mathrm{~S} 2$ were higher than in the treatment $\mathrm{C} 1 \mathrm{~S} 2$, but the total grains per panicle in the treatment $\mathrm{C} 2 \mathrm{~S} 2$ was lower than in the treatment C1S2. While, under the inorganic fertilizer alone, the number of effective panicles, the total grains per panicle and the grain yield in the treatment $\mathrm{C} 2 \mathrm{~S} 1$ were lower than in the treatment $\mathrm{C} 1 \mathrm{~S} 1$, the thousand-grain weight in the treatment $\mathrm{C} 2 \mathrm{~S} 1$ were higher than in the treatment C1S1. Furthermore, in the unfertilized control treatment, the treatment $\mathrm{C} 2 \mathrm{~S} 3$ had a lower number of effective panicles, but the total 
Table 2. Rice yield and composition by treatment.

\begin{tabular}{|c|c|c|c|c|c|}
\hline \multirow[b]{2}{*}{ Treatment } & \multicolumn{3}{|c|}{ Yield Composition } & \multirow{2}{*}{$\begin{array}{l}\text { Theoretical Yield } \\
\qquad\left(\mathrm{kg} \cdot \mathrm{hm}^{-2}\right)\end{array}$} & \multirow{2}{*}{$\begin{array}{c}\text { Grain Yield } \\
\left(\mathrm{kg} \cdot \mathrm{hm}^{-2}\right)\end{array}$} \\
\hline & $\begin{array}{l}\text { Effective Panicles } \\
\qquad\left(\mathrm{m}^{-2}\right)\end{array}$ & $\begin{array}{l}\text { Total Grains per } \\
\text { Panicle }\end{array}$ & $\begin{array}{c}\text { Thousand-grain Weight } \\
\left(\mathrm{g} \cdot 1000^{-1}\right)\end{array}$ & & \\
\hline C1S1 & 270 & 97 & 28.64 & 7500.8 & $7038.2 \mathrm{Aa}$ \\
\hline $\mathrm{C} 2 \mathrm{~S} 1$ & 259 & 89 & 30.15 & 6949.9 & $6715.3 \mathrm{Ba}$ \\
\hline $\mathrm{C} 1 \mathrm{~S} 2$ & 261 & 102 & 28.07 & 7472.8 & $7100.5 \mathrm{Ab}$ \\
\hline $\mathrm{C} 2 \mathrm{~S} 2$ & 277 & 98 & 30.62 & 8312.0 & 7585.4 Bab \\
\hline $\mathrm{C} 1 \mathrm{~S} 3$ & 217 & 62 & 25.47 & 3426.7 & $3014.4 \mathrm{Ac}$ \\
\hline $\mathrm{C} 2 \mathrm{~S} 3$ & 206 & 70 & 26.83 & 3868.9 & $3421.5 \mathrm{Bc}$ \\
\hline Irrigation $\times$ Fertilizer & ns & $*$ & ns & $*$ & $*$ \\
\hline
\end{tabular}

ANOVA results of no significance (ns) at $\mathrm{P}>0.05$ or significant differences $(*)$ at $\mathrm{P} \leq 0.05$.

For the same fertilization treatment, significantly effects of different irrigation conditions on yield were shown by capital letters (A or B), while for the same irrigation method, the effect of different fertilization treatment on yield were shown by lowercase letters $(\mathrm{a}, \mathrm{b}$, or $\mathrm{c})$.

grains per panicle, higher the thousand-grain weight and the grain yield with the treatment C1S3. When compared with the treatment $\mathrm{C} 1 \mathrm{~S} 1$, the treatment $\mathrm{C} 2 \mathrm{~S} 2$ increased the number of effective panicles by $2.6 \%$, the thousand-grain weight by $6.9 \%$ and the grain yield by 7.8\%. Therefore, the treatment $\mathrm{C} 2 \mathrm{~S} 2$ showed a clear increase in production when compared to the treatment C1S1. Overall, the different fertilization methods had a significant impact on the yield $(\mathrm{P} \leq 0.05)$, the yield effects of the irrigation method were not significant $(\mathrm{P}>0.05)$; while the combined yield effect of irrigation and fertilizer application was significant $(\mathrm{P} \leq 0.05)$.

\section{Interaction}

Generally, the results showed that the interaction between irrigation regimes and fertilizers was significant on the plant growth metrics (plant height, leaf area index, dry matter accumulation and yield) (Figs 1-3). According to previous studies, the effects of different fertilizer compounds on rice yield and dry matter accumulation were significant [22-24]. Controlled irrigation could increase the nitrogen fertilizer absorption ability of the rice, improving the distribution of dry matter and increasing production [25-29], which we found to be true in this study. The interaction between irrigation and fertilizer regimes could enhance the positive effect on panicle numbers per $\cdot \mathrm{m}^{-2}$, as well as promote rice production. Our results are in agreement with Fazli Hameed et al. [30] who reported that there was still a scope of high yield with lower nitrogen and water applications. The rice plots in the $\mathrm{C} 2 \mathrm{~S} 2$ treatment showed increased production effects when compared to other treatments, which was likely due to soil moisture under the conditions of the controlled irrigation being more conducive to the efficient use of the organic fertilizer.

\section{N Concentration in Different Soil Layers}

The changes in total $\mathrm{N}(\mathrm{TN})$, ammonium $\mathrm{N}$ $\left(\mathrm{NH}_{3}-\mathrm{N}\right)$, and nitrate $\mathrm{N}(\mathrm{NO}-\mathrm{N})$ concentrations in the soil after fertilization are shown in Figs 4-6. Overall, after applying fertilizer, the changes of nitrogen concentrations with different forms in the soil decreased with time afterward. Under the same fertilizer application amount, the TN content in the soil of the conventional irrigation treatment was slightly higher than that of the controlled irrigation treatment. In inorganic fertilizer treatment, the soil $\mathrm{TN}$ content in the $0-20 \mathrm{~cm}$ layer decreased by $37.9 \%$ and $49.2 \%$ for C1S1 and C2S1, respectively, and decreased by $31.7 \%$ and $42.3 \%$ in the $20-40 \mathrm{~cm}$ layer, respectively, within 11 days after fertilization. In organic and inorganic fertilizer treatment, TN concentration in soil presents a trend from increase gently within the first three days, and to decrease sharply thereafter. Overall, the soil TN content in the $0-20 \mathrm{~cm}$ layer decreased by $37.9 \%$ and $49.2 \%$ for $\mathrm{C} 1 \mathrm{~S} 2$ and $\mathrm{C} 2 \mathrm{~S} 2$, respectively, and decreased by $31.7 \%$ and $42.3 \%$ in the $20-40 \mathrm{~cm}$ layer, respectively, within 11 days after fertilization. Under the same irrigation application amount, TN content decreased with increased soil depth and also decreased with time under each fertilization treatment. The TN content of soil in the combined application of organic and inorganic fertilizer treatment was higher than that in the single-application chemical fertilizer and no fertilizer treatments. The results showed that the soil $\mathrm{N}$ absorbed and utilized by rice was not mainly from the chemical fertilizer, and that the combined application of organic and inorganic fertilizer could significantly improve $\mathrm{N}$ fertility. In the combined application of organic and inorganic fertilizer treatment, the $\mathrm{TN}$ content in the soil was relatively high, but it decreased rapidly with time. Therefore, organic fertilizer promoted the decomposition and transformation of $\mathrm{TN}$ in the soil. In 

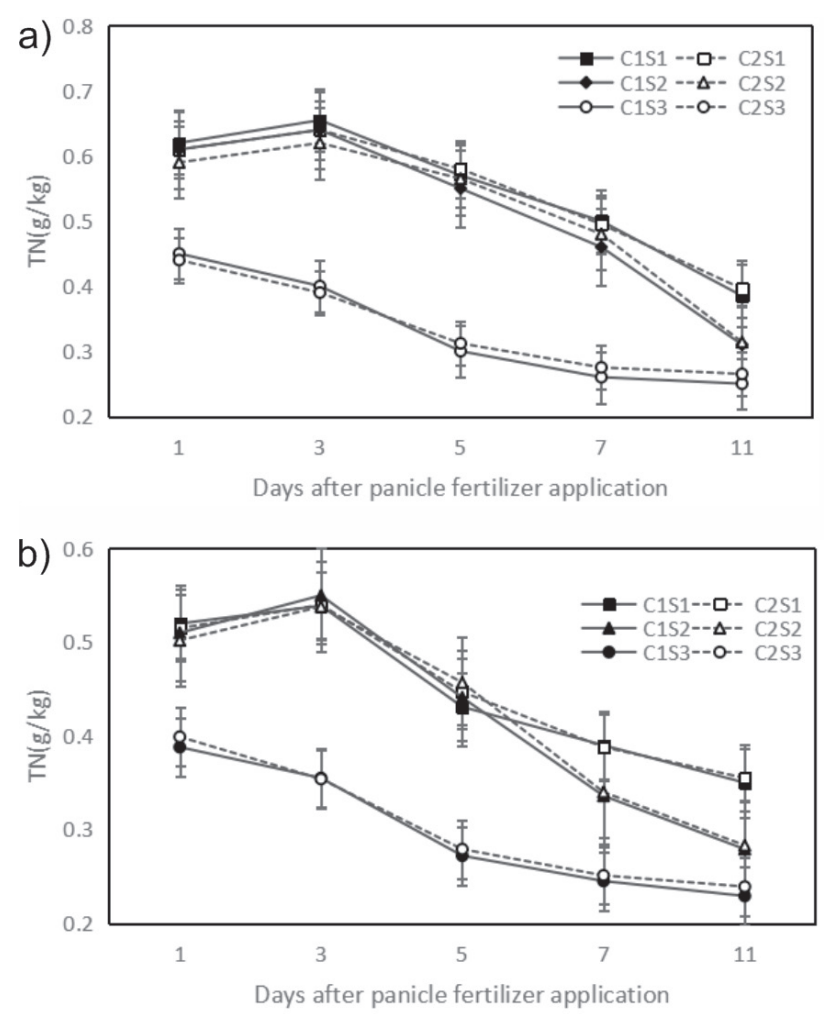

Fig. 4. Variation of the total nitrogen content in different soil layers after panicle fertilizer application: a) $0-20 \mathrm{~cm}$; and b) $20-40 \mathrm{~cm}$.
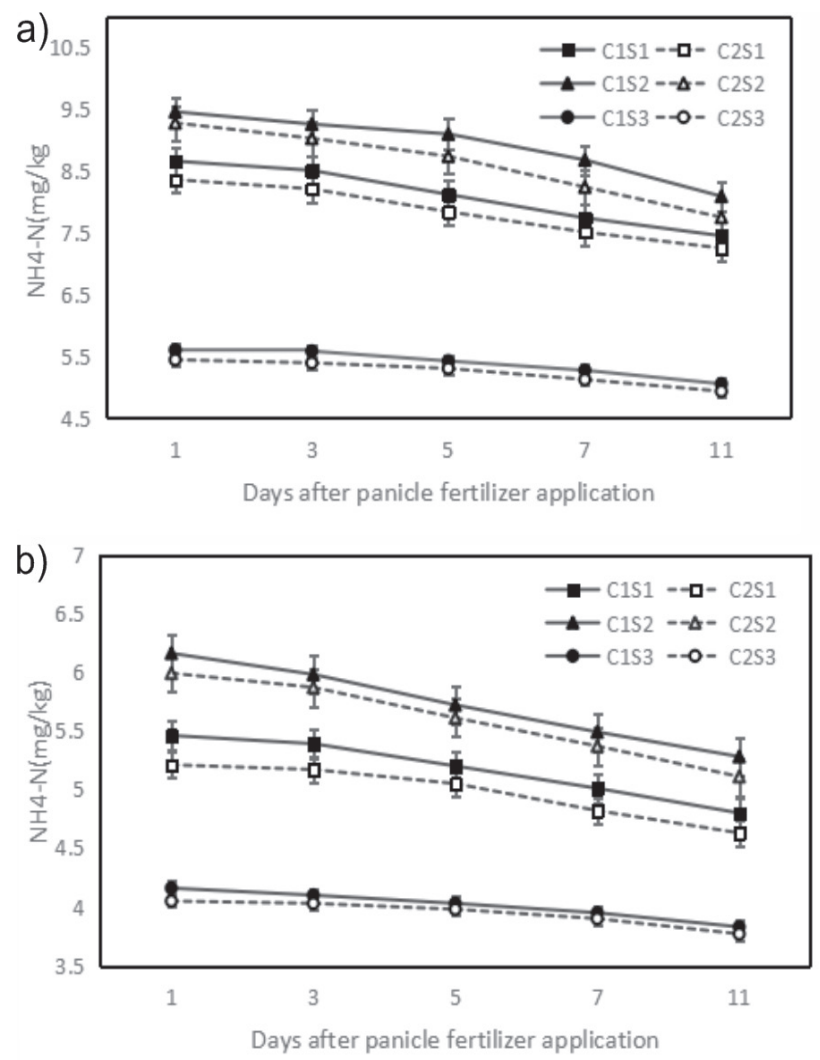

Fig. 5. $\mathrm{NH}_{3}-\mathrm{N}$ concentrations in different soil layers: a) $0-20 \mathrm{~cm}$; and b) $20-40 \mathrm{~cm}$.
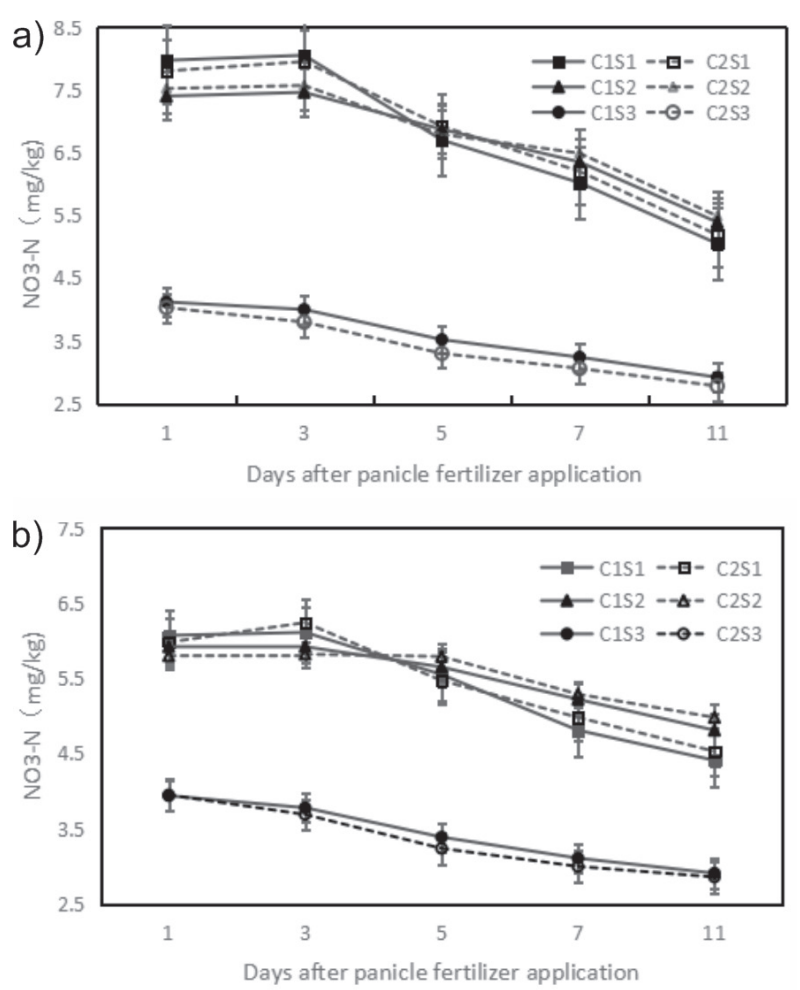

Fig. 6. NO-N concentration concentrations change curve in different soil layers: a) 0-20 cm; and b) 20-40 cm.

the $\mathrm{C} 2 \mathrm{~S} 2$ treatment, the $\mathrm{C} 2 \mathrm{~S} 1$ treatment and the $\mathrm{C} 2 \mathrm{~S} 3$ treatment, the $\mathrm{TN}$ contents in the $0-20 \mathrm{~cm}$ soil layer decreased by $46.7 \%, 35.1 \%$, and $39.8 \%$, respectively, and decreased by $43.6 \%, 31.1 \%$, and $40.1 \%$ in the 2 $0-40 \mathrm{~cm}$ soil layer, respectively. The changes in $\mathrm{TN}$ content were the most obvious $(\mathrm{P} \leq 0.05)$. Within the controlled irrigation, the effect orders of nitrogen factors on $\mathrm{TN}$ were as follows, $\mathrm{C} 2 \mathrm{~S} 2>\mathrm{C} 2 \mathrm{~S} 1>\mathrm{C} 2 \mathrm{~S} 3$. This was because the microbial activity in the soil after the combined application of organic and inorganic fertilizers was relatively large, inducing rapid $\mathrm{N}$ transformations and migrationInorganic $\mathrm{N}$ in the soil mainly consisted of ammonium $\mathrm{N}$ and nitrate $\mathrm{N}$. As shown in Fig. 5, the soil nitrate- $\mathrm{N}$ content was decreasing with time because of crop uptaking, nitrogen leaching and denitrification. Under the same fertilizer application amount, the content of ammonium $\mathrm{N}$, the soil nitrate nitrogen content under conventional irrigation was lower than controlled irrigation treatment because of nitrate nitrogen migration deeper into soil with water. In the monitoring stage, the content of nitrate $\mathrm{N}$ in the $0-20 \mathrm{~cm}$ soil layer decreased by $37.3 \%$ and $37.0 \%$ in the treatment $\mathrm{C} 1 \mathrm{~S} 2$ and $\mathrm{C} 2 \mathrm{~S} 2$. And it showed that the content of nitrate $\mathrm{N}$ decreased by $23.5 \%$ and $16.6 \%$ under the treatment $\mathrm{C} 1 \mathrm{~S} 2$ and $\mathrm{C} 2 \mathrm{~S} 2$, in the $20-40 \mathrm{~cm}$ soil layer. There is was not a significant difference of nitrate nitrogen content in each soil layer under two irrigation modes. Under the same irrigation conditions, the content of nitrate nitrogen with combined application of organic fertilizer in each soil layer at the beginning 
was lower than that of single application of chemical fertilizer, while at the end of monitoring cycle which was higher than that of in the application of chemical fertilizer alone. In the monitoring stage, the content of nitrate $\mathrm{N}$ in the $0-20 \mathrm{~cm}$ soil layer decreased by $50.3 \%$ and $37.0 \%$ in the treatment $\mathrm{C} 2 \mathrm{~S} 1$ and $\mathrm{C} 2 \mathrm{~S} 2$. And it showed that the content of nitrate $\mathrm{N}$ decreased by $32.0 \%$ and $16.6 \%$ under the treatment $\mathrm{C} 2 \mathrm{~S} 1$ and $\mathrm{C} 2 \mathrm{~S} 2$, in the $20-40 \mathrm{~cm}$ soil layer.

The content of ammonium $\mathrm{N}$ treated with the treatment $\mathrm{C} 2 \mathrm{~S} 2$ was higher than that for the treatments $\mathrm{C} 2 \mathrm{~S} 1$ and $\mathrm{C} 2 \mathrm{~S} 3$, and the gap of ammonium $\mathrm{N}$ content between the treatment $\mathrm{C} 2 \mathrm{~S} 2$ and $\mathrm{C} 2 \mathrm{~S} 1$ decreased gradually with increasing soil depth. Under the same irrigation conditions, the content of ammonium $\mathrm{N}$ in the $0-20 \mathrm{~cm}$ soil layer decreased by $16.5 \%$ in the treatment $\mathrm{C} 2 \mathrm{~S} 2$ in the monitoring stage, decreased by $13.2 \%$ in the treatments $\mathrm{C} 2 \mathrm{~S} 1$, and decreased by $9.4 \%$ in the treatment $\mathrm{C} 2 \mathrm{~S} 3$. And it showed that the content of ammonium $\mathrm{N}$ decreased by $14.7 \%, 11.1 \%$, and $7.0 \%$ under the treatment $\mathrm{C} 2 \mathrm{~S} 2, \mathrm{C} 2 \mathrm{~S} 1$, and $\mathrm{C} 2 \mathrm{~S} 3$, respectively, in the 20-40 cm soil layer. The C2S2 was beneficial for the conversion of ammonium $\mathrm{N}$ in the topsoil, causing less residue in the soil.

\section{Nitrogen Accumulation}

The $\mathrm{N}$ accumulation in the straw and grain at harvest is shown in Fig. 7. The total accumulative $\mathrm{N}$ uptake ranged from $49.27 \mathrm{~kg} / \mathrm{ha}$ to $93.52 \mathrm{~kg} / \mathrm{ha}$, the treatment $\mathrm{C} 2 \mathrm{~S} 3$ had the lowest $\mathrm{N}$ accumulation. The total accumulation of $\mathrm{N}$ in above-ground biomass under different irrigation regimes was in the following order: under the combined organic and inorganic fertilizer was $\mathrm{C} 1 \mathrm{~S} 2>\mathrm{C} 2 \mathrm{~S} 2$; while under the chemical fertilizer alone was $\mathrm{C} 2 \mathrm{~S} 1>\mathrm{C} 1 \mathrm{~S} 1$. Under the same irrigation application amount, the total accumulation of $\mathrm{N}$ in the aboveground biomass was in the following order: combined organic and inorganic fertilizer>inorganic fertilizer alone $>$ no fertilizer. Therefore, combined applications of organic and inorganic fertilizer were beneficial to $\mathrm{N}$ accumulation in the above-ground biomass, but the

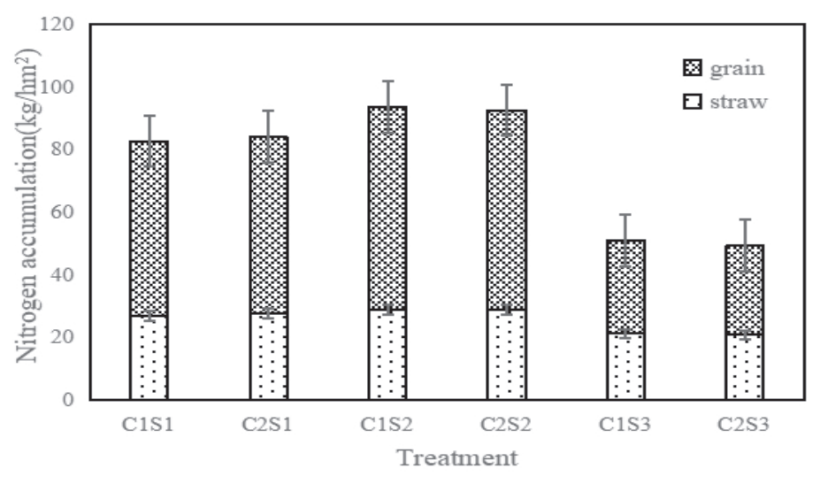

Fig. 7. Nitrogen accumulation and distribution in harvested rice (straw and grain) for different treatments. effect of water conditions on $\mathrm{N}$ accumulation varied with fertilizer conditions. The total accumulation of $\mathrm{N}$ in rice grains and the total accumulation of $\mathrm{N}$ in the above-ground biomass at harvest in the treatment $\mathrm{C} 1 \mathrm{~S} 1$, the treatment $\mathrm{C} 2 \mathrm{~S} 1$, the treatment $\mathrm{C} 1 \mathrm{~S} 2$, the treatment $\mathrm{C} 2 \mathrm{~S} 2$, the treatment $\mathrm{C} 1 \mathrm{~S} 3$, and the treatment C2S3 accounted for $67.62 \%, 67.20 \%, 69.10 \%, 68.75 \%$, $58.43 \%$, and $57.75 \%$, respectively. Fertilizer status had a significant effect on the accumulation of $\mathrm{N}$ content in grains $(\mathrm{P} \leq 0.05)$, while the irrigation mode had no significant effect on the accumulation of $\mathrm{N}$ in the grains or straws $(\mathrm{P}>0.05)$.

\section{Nitrogen Use Efficiency}

Nitrogen use efficiency (NUE) refers to the percentage of the applied chemical $\mathrm{N}$ fertilizer that is absorbed by rice in the current season, which is an important indicator of rice $\mathrm{N}$ utilization [16, 31]. The agronomy efficiency of $\mathrm{N}$ under the combined application of organic and inorganic fertilizer was significantly higher than for the single application of a chemical fertilizer. As shown in Table 3, the average NUE in the combined application of organic and inorganic fertilizer treatment was $12.8 \%$ higher than in the inorganic fertilizer alone treatment. The conventional irrigation treatment was $8.8 \%$ higher than the controlled irrigation treatment. The average physiological efficiency of $\mathrm{N}$ in the organic and inorganic fertilizer treatment was $15.3 \%$ lower than that of the inorganic fertilizer alone treatment, and the controlled irrigation treatment was $17.0 \%$ lower than the conventional irrigation treatment. The NUE values showed that the organic and inorganic fertilizer treatment was higher than the inorganic fertilizer alone treatment, and the controlled irrigation treatment was higher than that of the conventional irrigation treatment. Thus, changes in the $\mathrm{N}$ efficiency were the result of the water-fertilizer coupling.

\section{Discussion}

In this study, in comparison with the conventional irrigation treatment, the plant height was slightly lower in the controlled irrigation treatment conditions, and the similar conclusion was drawn by Liu. [32] This disparity in plant height with irrigation treatment was because the water-saving irrigation condition in the middle and late stages promoted the transformation of vegetative growth to reproductive growth, thus inhibiting any excessive increases in plant height, and facilitating the formation of compact bottom dwarf inter-nodes of rice. These effects were beneficial to increase the formation of photosynthetic products, which was conducive to increasing the yield potential of the rice plants.

Wei et al. [20] found that water and fertilizer coupling promoted growing development of rice, and the LAI increased rapidly. As expected, the controlled 
Table 3. Indicators of nitrogen fertilizer use efficiency.

\begin{tabular}{|c|c|c|c|c|c|c|c|}
\hline Treatment & $\mathrm{F}_{\mathrm{N}}{ }^{*}$ & Yield & $\mathrm{U}_{\mathrm{N}}$ & $\mathrm{AE}_{\mathrm{N}}$ & $\mathrm{PE}_{\mathrm{N}}$ & $\mathrm{SE}_{\mathrm{N}}$ & $\mathrm{E}_{\mathrm{N}}$ \\
\hline & $\left(\mathrm{kg} \mathrm{hm}^{-2}\right)$ & $\left(\mathrm{kg} \mathrm{hm}{ }^{-2}\right)$ & $\left(\mathrm{kg} \mathrm{hm}^{-2}\right)$ & $\left(\mathrm{kg} \mathrm{kg}^{-1}\right)$ & $\left(\mathrm{kg} \mathrm{kg}^{-1}\right)$ & $\left(0.01 \mathrm{~kg} \mathrm{~kg}^{-1}\right)$ & $\left(\mathrm{kg} \mathrm{kg}^{-1}\right)$ \\
\hline $\mathrm{C} 1 \mathrm{~S} 1$ & 210 & $7038.2 \mathrm{Aa}$ & 82.71 & $19.16 \mathrm{Aa}$ & $127.01 \mathrm{Aa}$ & $15.09 \mathrm{Aa}$ & $75.09 \mathrm{Aa}$ \\
\hline $\mathrm{C} 2 \mathrm{~S} 1$ & 210 & $6715.3 \mathrm{Ba}$ & 84.05 & $15.68 \mathrm{Ba}$ & $94.70 \mathrm{Ba}$ & $16.56 \mathrm{Ba}$ & $79.9 \mathrm{Ba}$ \\
\hline $\mathrm{C} 1 \mathrm{~S} 2$ & 210 & $7100.5 \mathrm{Ab}$ & 93.52 & $19.46 \mathrm{Ab}$ & $96.17 \mathrm{Ab}$ & $20.23 \mathrm{Ab}$ & $75.92 \mathrm{Ab}$ \\
\hline $\mathrm{C} 2 \mathrm{~S} 2$ & 210 & $7585.4 \mathrm{Bab}$ & 92.58 & $19.83 \mathrm{Bb}$ & $96.14 \mathrm{Bb}$ & $20.62 \mathrm{Bb}$ & $81.93 \mathrm{Bb}$ \\
\hline $\mathrm{C} 1 \mathrm{~S} 3$ & - & $3014.4 \mathrm{Ac}$ & 51.03 & - & - & - & $59.07 \mathrm{Ac}$ \\
\hline $\mathrm{C} 2 \mathrm{~S} 3$ & - & $3421.5 \mathrm{Bc}$ & 49.27 & - & - & - & $69.44 \mathrm{Bc}$ \\
\hline
\end{tabular}

With each column, values followed by different letters are significantly different at the 0.05 probability level according to ANOVA. ${ }^{*} \mathrm{~F}_{\mathrm{N}}=$ the amount of $\mathrm{N}$ fertilizer applied.

$\mathrm{U}_{\mathrm{N}}=$ Total $\mathrm{N}$ accumulation plants in the plot that received $\mathrm{N}$ fertilizer.

irrigation had less effect on the plant height, while the organic and inorganic fertilizers significantly reduced the plant height. And The C2S2 treatment had a significantly higher the plant height and LAI compared with the other treatments. The reason might be that the controlled irrigation condition promoted the transformation of vegetative growth to reproductive growth, thus inhibiting any excessive increases in plant height, and to improved soil ventilation making the root system more developed. These effects were beneficial to increase the formation of photosynthetic products, which was conducive to increasing the yield potential of the rice plants. In addition, the organic and inorganic fertilizers made soil nutrients abundant, which was conducive to rice plant and leaf growth and delayed a decrease in the LAI, thus, this treatment was conducive to the accumulation of photosynthate.

Anzona et al. [33] found that a larger LAI was one important factor to enhance rice photosynthesis, productive panicles and, an increased grain yield. Jun et al. [19] found that the productive panicles per $\mathrm{m}^{2}$ was influenced by the tiller number and total grains per panicle, thus with the increasing of the tiller number and

Table 4. Correlation matrix for grain yield, productive panicles, thousand-grain weight, total $\mathrm{N}$ uptake, and soil total nitrogen.

\begin{tabular}{|c|c|c|c|c|c|}
\hline & GY & PP & TGW & TNU & STN \\
\hline GY & 1 & $0.87^{* *}$ & $0.67^{*}$ & $0.89^{* *}$ & $0.53^{*}$ \\
\hline PP & & 1 & $0.53^{\text {ns }}$ & $0.65^{\text {ns }}$ & $0.028^{\text {ns }}$ \\
\hline TGW & & & 1 & $0.62^{*}$ & $0.52^{*}$ \\
\hline TNU & & & & 1 & $0.71^{* *}$ \\
\hline STN & & & & & 1 \\
\hline
\end{tabular}

$*$, ** and ns denote significance at the $5 \%$ and $1 \%$ level of probability and non-significance, respectively.

GY, PP, TGW, TNU and STN represent grain yield, productive panicles, thousand-grain weight, total $\mathrm{N}$ uptake, and soil total nitrogen, respectively. total grains per panicle, may lead to the increase of the grain yield. Huang et al. [34] also found panicle per $\mathrm{m}^{2}$ played a critical role in increasing grain production. In this study, under the same fertilizer application amount, there was no significance on total grains per panicle, thousand-grain weight and the yield for the irrigation treatment. Under the same irrigation application amount, the fertilizer treatments had a significant effect on total grains per panicle growth during all the different growth stages, while the thousand-grain weight and the yield were not significant. Also, the interaction between irrigation and fertilization was significant. It was clear that nitrogen fertilizer played an important role in rice yield formation.

\section{Effects of Irrigation and Fertilization on Nitrogen Accumulation and Utilization}

In our study, the pathways for $\mathrm{N}$ loss in the topsoil of the paddy fields mainly included absorption and utilization by the rice, ammonia volatilization, and loss via surface runoff. In contrast, the pathways for deep soil $(20-40 \mathrm{~cm}) \mathrm{N}$ loss were mainly due to absorption and utilization of rice as well as and leaching, which coincided with the research of Jun et al. [19]. Many previous studies have highlighted that an application of inorganic fertilizer alone causes high losses of nutrients, especially $\mathrm{N}$. These high $\mathrm{N}$ losses lead to environmental pollution, including water eutrophication, groundwater pollution, and emissions of greenhouse gases [35]. Sun et al. [36] indicated that nitrate $\mathrm{N}$ was the main form of $\mathrm{N}$ in the soil, and the input of organic fertilizer was effective at reducing the soil ammonium $\mathrm{N}$ content in the soil. The papers on the same experiment have showed that organic fertilizers application increased the total nitrogen content and the nitrate nitrogen content, and it was effective at reducing the soil ammonium $\mathrm{N}$ content in the soil. [36, 37] These research results are the same with the present study. Wang et al. [38] found that water and fertilizer were important factors determining nitrate leaching. Rational applications of 
organic fertilizer could help to reduce the accumulation of nitrate $\mathrm{N}$ in soils, and also reduce the risk of nitrogen loss [39]. This result also occurred in the present study, the controlled irrigation was conducive to the absorption and utilization of nutrient elements by roots, causing the residual $\mathrm{N}$ content in the soil to be relatively low. Maintaining the same $\mathrm{N}$ rate and replacing chemical fertilizers with organic fertilizers could effectively reduce the $\mathrm{N}$ concentration in paddy soils, thereby reducing the risk of $\mathrm{N}$ loss. To alleviate the losses of $\mathrm{N}$ and improve fertilizer efficiency, using a combination of organic-inorganic fertilizer applications and controlled irrigation was recommended. The combined application of organic and inorganic fertilizers combine the quickacting characteristics of chemical fertilizers with the persistence of organic fertilizers. This combination has been shown to improve land productivity and soil properties [40-43].

According to some studies, optimization of water and nitrogen management for paddy soils could significantly enhance water and fertilizer use efficiency [44,45]. In this study, we observed that $\mathrm{N}$ fertilizer use efficiency increased in the $\mathrm{C} 2 \mathrm{~S} 2$ treatment, while the $\mathrm{N}$ utilization efficiency varied with water conditions. Therefore, the efficient use of $\mathrm{N}$ fertilizer in a paddy field was the result of the combined effect of water and $\mathrm{N}$, which coincided with the research of other researches. We observed that the $\mathrm{N}$ accumulation, $\mathrm{N}$ use efficiency, and there were significant correlations between grain yield, productive panicles, thousand-grain weight, total $\mathrm{N}$ uptake, and soil total $\mathrm{N}$ (Tables $3 \& 4$ ). As shown in Table 4, productive panicles were significantly related to grain yield with a correlation coefficient of 0.87 , and total $\mathrm{N}$ uptake was most significantly related to grain yield with a correlation coefficient of 0.89 . In the present study, internal $\mathrm{N}$ utilization efficiency was influenced by irrigation and fertilization. With inorganic fertilizer application alone, the fertilizer efficiency response to rice was very low, while the combined application of organic and inorganic fertilizers was beneficial to nutrient accumulation and promoted nutrition resource utilization efficiency. Given this situation, it was easy to understand the recommendation of S.K. White [46] to stop applying chemical fertilizer alone, and instead maintain organic inputs. As such, it is necessary to increase both yields and $\mathrm{N}$ use efficiency to avoid environmental problems associated with excessive inorganic fertilizer applications and irrigation, as well as to improve the profitability of rice production.

The application of organic fertilizer plays an active role in regulating nitrogen fertilization supply and nitrogen distribution, thus contributing to improving $\mathrm{N}$ use efficiency. Although the $\mathrm{N}$ supply capacity in the early stage is not as good as that in the single application of chemical fertilizers, the $\mathrm{N}$ nutrition status of the rice in later growth periods was better than that of the chemical fertilizer application alone, particularly with the release of organic fertilizer N. Organic fertilizers not only supplement the soil nutrients in the paddy field, but also regulate the release intensity and rate of soil and chemical fertilizer nutrients. As a result, the rice receives more balanced nutrition during each growing stage.

\section{Conclusions}

In this study, we highlighted that the integrated application of organic and inorganic fertilizers and controlled irrigation is effective at enhancing the growth, yield, and yield components of rice. The C2S2 treatment showed the best performance in terms of $\mathrm{N}$ use efficiency, growth parameters, and rice yield. The controlled irrigation and organic and inorganic combination of fertilization used in our study had a number of advantages, including promoting $\mathrm{N}$ use efficiency, effectively reducing the $\mathrm{N}$ concentration in soil, and reducing the risk of $\mathrm{N}$ loss. It is essential to find ways to reduce environmental impacts in order to meet increasing consumer demands and sustainability goals. Considering the negative effects of conventional irrigation and fertilization methods, the combined application of organic and inorganic fertilizers with controlled irrigation was useful not only for improving rice yield, but also for promoting sustainable agricultural practices.

Compared to regular irrigation and fertilization methods, we found that controlled irrigation and the use of a combination of organic and inorganic fertilization had several advantages. While controlled irrigation and organic and inorganic fertilization showed potential for improving the efficiency of $\mathrm{N}$ use and the resulting grain yield, our results suggest that other factors, such as crop establishment, plant density, and pest management, are limiting yields, which must be understood and addressed before considering methods for improving $\mathrm{N}$ efficiency and crop yields.

\section{Conflict of Interest}

The authors declare no conflict of interest.

\section{References}

1. YANG S., PENG S., XU J., HOU H., GAO X. Nitrogen Loss from Paddy Field with Different Water and Nitrogen Managements in Taihu Lake Region of China. Communications in Soil Science and Plant Analysis. 44 (16), 2393, 2013.

2. GENG Y., LU W., JIANG Y. Effects of Organic Fertilizer Application on Nutrient Leaching in Preferential Flow of Soil. Journal of Agro-Environment Science. 4, 1454, 2007.

3. MENG L.,WANG Q., HUANG Q., YANG X., XU Y.,SHEN Q. Effects of Combined Application of Pig Manure Compost and Inorganic Fertilizers on Yield of Rice Grains and Nitrogen Use Efficiency. Journal of Ecology and Rural Environment, 24 (1), 68, 2008. 
4. YU J., JIANG Y., XU C., SHEN Q., XU Y. Effects of combined application of inorganic fertilizer with straw and pig slurry and their compost on wheat growth and nitrogen uptake. Plant Nutrition and Fertilizer Science, 18 (06), 1293, 2012.

5. BANDYOPADHYAY K., MISRA A., GHOSH P., HATI K. Effect of integrated use of farmyard manure and chemical fertilizers on soil physical properties and productivity of soybean. Soil \& Tillage Research, 110 (1), 115, 2010.

6. LI D., CHEN L., XIA Y., SONG X., LIU M., ZHENG J. The effects of biochar on growth and uptake of nitrogen and phosphorus for Chinese cabbage in poor quality soil in Ningxia. Acta Scientiae Circumstantiae, 34 (9), 2384, 2014.

7. SHEORAN, S., ANTIL, R., DEVRA, DEEPIKA, GREWAL K. Yield trends and changes in soil fertility in a long term pearl millet (Pennisetum glaucum)-wheat (Triticum aestivum) cropping system managed with organic, inorganic and integrated sources of nutrients. Indian Journal of Agricultual Sciences, 88 (10), 1521, 2018.

8. LUNDY M., SPENCER D., VAN K., HILL J., LINQUIST B. Managing phosphorus fertilizer to reduce algae, maintain water quality, and sustain yields in water-seeded rice. Field Crops Research, 131,81, 2012.

9. BRAR B., SINGH K., DHERI G., BALWINDERKUMAR. Carbon sequestration and soil carbon pools in a rice-wheat cropping system: Effect of long-term use of inorganic fertilizers and organic manure. SOIL \& TILLAGE RESEARCH. 128, 36, 2013.

10. YANG B., CHEN X., ZHANG Y., YAO S., ZANG G., YOU Y. Application of water-saving irrigation technologies and pollution control in paddy fields of Taihu Basin. China Water Resources. 7, 55, 2018.

11. JIN Z., PAN G., LI L. Community structure characters and differences of $\mathrm{N}_{2}$ fixing and $\mathrm{CO}_{2}$ fixing bacteria under longterm fertilization in paddy soils of Taihu Lake region, China. Plant Nutrition and Fertilizer Science. 19 (01), 82, 2013.

12. LENTZ R., LEHRSCH G. Mineral Fertilizer and Manure Effects on Leached Inorganic Nitrogen, Nitrate Isotopic Composition, Phosphorus, and Dissolved Organic Carbon under Furrow Irrigation.[J]. Journal of environmental quality, 47 (2), 287, 2018.

13. YE Y., LIANG X., ZHOU K., LI L., JIN Y., ZHU C., ZHAO Y. Effects of water-saving irrigation and controlledrelease fertilizer application on nitrogen leaching loss of paddy soil in Taihu Lake region. Acta Scientiae Circumstantiae, 35 (1), 270, 2015.

14. LI Y., SHAO X., LI D., XIAO M., HU X., JING H. Effects of water and nitrogen coupling on growth, physiology and yield of rice. International Journal of Agricultural and Biological Engineering, 12 (3), 66, 2019.

15. LIU Y., SUN W., JUAN Y. Effects of Water Control on Growth and Yield of Rice. Jiangsu Agricultural Sciences, 46 (4), 53, 2018.

16. ZHU Q., DENG C., YE J., LIANG S., YUE H., ZHAN M., LI Y., CHEN Q. Relationships between rice leaf area index and yield at different growth stages. Journal of Zhongkai University of Agriculture and Engineering. 29 (03), 17, 2016.

17. BORGOGNONE D., COLLA G., ROUPHAEL Y., CARDARELLI M., REA E., SCHWARZ D. Effect of nitrogen form and nutrient solution $\mathrm{pH}$ on growth and mineral composition of self-grafted and grafted tomatoes. Scientia Horticulturae, 149, 61, 2013.
18. BAO S., Soil and Agricultural Chemistry Analysis. China Agriculture Press, 2016.

19. QIAO J., YANG L., YAN T., XUE F., ZHAO D. Rice dry matter and nitrogen accumulation, soil mineral $\mathrm{N}$ around root and $\mathrm{N}$ leaching, with increasing application rates of fertilizer. European Journal of Agronomy. 49, 93, 2013.

20. LI Y., SHAO X., GUAN W., REN L., LIU J., WANG J., WU Q. Nitrogen-Decreasing and Yield-Increasing Effects of Combined Applications of Organic and Inorganic Fertilizers under Controlled Irrigation in a Paddy Field. Polish Journal of Environmental Studies, 25 (2), 673, 2016.

21. WEI Y., HE S., XU C. Influence of Water-Fertilizer Coupling on Rice LAI and Yield under the Condition of Controlling Irrigation. System sciences and comprehensive studies in agriculture, 26 (04), 500, 2010.

22. GU W., GU S., ZHANG Q., SHEN J., YUAN W. Effect of combination application of organic and inorganic fertilizer on the yield and yield components of rice. Acta Agriculture Shanghai. 31 (06), 95, 2015.

23. MA Y., QIAN C., DENG L., HUANG G. Effects of Combining Chinese Milk Vetch With Nitrogen Fertilizer on Grain and Dry Matter Yield, Nitrogen Absorption and Utilization of Double-cropping Rice. Journal of Nuclear Agricultural Science. 31 (12), 2399, 2017.

24. YU X., ZHAI B., JIN Z., LI Y., WANG Y., ZHANG H., WANG C. Effect of Combined Application of Organic and Inorganic Fertilizers on Winter Wheat yield, Water and Fertilizer Use Efficiency and Soil Fertility in Dry land. Journal of Soil and Water Conservation. 29 (05), 320, 2015.

25. DUAN P., ZHANG Y., CONG Y., XU W., LU N., ZHANG Y. Regulation of soil fixed ammonium and soluble $\mathrm{N}$ through combined application of $\mathrm{N}$ fertilizer and manure. Journal of Plant Nutrition and Fertilizer. 22 (06), 1578, 2016.

26. GUO Q., HE W. Effects of Water and Nitrogen Interaction on Yield and Quality of Rice. Water Saving Irrigation. (05), 42, 2016.

27. SHAO S., MA B., CHANG Y., JING W., HOU D., ZHAO B., ZHANG H. Research Progress on Effects of Interactions between Water and Nitrogen on Yield Formation in Rice. China Rice. 25 (03), 21, 2019.

28. LI Y. Studies on effects and mechanisms of water conditions and nitrogen fertilizer levels on nitrogen use efficiency in a rice cropping system. Zhejiang University. 2012.

29. HE H., WU J., ZENG Y., HU K., HUANG S., ZENG Y., PAN X., SHI Q. Effects of nitrogen management on yield and nitrogen utilization of double cropping late rice under total rice straw incorporation. Journal of Plant Nutrition and Fertilize. 20 (04), 811, 2014.

30. HAMEED F., XU J., RAHIM S., WEI Q., KHALIL A., LIAO Q. Optimizing Nitrogen Options for Improving Nitrogen Use Efficiency of Rice under Different Water Regimes. Agronomy-Basel, 9 (1), 2019.

31. DING W., XU X., HE P., ULLAH S., ZHANG J., CUI Z., ZHOU W. Improving yield and nitrogen use efficiency through alternative fertilization options for rice in China: A meta-analysis. Field Crops Research. 227, 11, 2018.

32. LIU Y. Rice physiology and yield and microbial ecology in paddy soil under different irrigation methods and fertilization. Nanning: Guangxi University, 2012 [In Chinese].

33. ANZONA K., KASHIWAGI J., TOSHIHIRO H., KAZUTO I., YUTAKA J. Genetic improvements for high yield and low soil nitrogen tolerance in rice (Oryza sativa 
L.) under a cold environment. Field Crops Research 116, 38-45, 2010.

34. HUANG J.B., FAN X.H., ZHANG S., GE G., SUN Y., FENG X. Investigation on the economically-ecologically appropriate amount of nitrogen fertiliser applied in rice production in Fe-leaching-stagnic anthrosols of the Taihu Lake region. Acta Ecologica Sinica, 27 (2), 588, 2007 [In Chinese with English abstract].

35. SPIERTZ J. Nitrogen, sustainable agriculture and food security: Areview. Agron. Sustain. 30 (1), 43, 2010.

36. SUN R., WANG D., LIN J., LIU Q., YANG L. Effects of Long Term Integrated Fertilization with Organic Manure and Chemical Fertilizers on Soil Nutrients in Taihu Lake Region. Soils. 41 (03), 384, 2009.

37. PENG N., WANG K., XIE X., WANG K. Effects of Longterm Integrated Fertilization with Organic Manure and Chemical Fertilizers on Soil Nutrients. Hubei Agricultural Sciences, 48 (02), 310, 2009.

38. WANG B., DAI M. Simulated Study on Movement Features of Soil Nitrogen in Different Forms in Soil Profile. Research of Soil and Water Conservation. 7 (4), 117, 2000.

39. JI Y. Effect of manure amendment on soil nitrate leaching potential and distribution of soil $15 \mathrm{~N}$ natural abundancce in paddy fields. ZheJiang University, 2014.

40. LI T., LI S., XIE Y., GAO Z., WANG R., MA H., LI L. Effect of Different Fertilizations Patterns on Soil Carbon and Nitrogen Changes of Dryland Wheat Field in Southern
Shanxi of China. Journal of Irrigation and Drainage. 37 (11), 43, 2018.

41. ZHANG J., ZHENG X., ZHANG H., LV W., LI S. Effects of Long-term Straw Returning and Nitrogen Fertilizer Regulation on Soil Quality and Yields of Rice Field. Acta Agriculturae Boreali-Sinica. 34 (01), 181, 2019.

42. HUANG T., XUN W., ZHANG R. Soil organic matter and crop yield with long-term fertilization schemes for an upland crop rotation in northern China. Journal of Zhejiang A \& F University. 34 (02), 253, 2017.

43. TAN X., SHAO D., LIU H., YANG F., XIAO C., YANG, $\mathrm{H}$. Effects of alternate wetting and drying irrigation on percolation and nitrogen leaching in paddy fields. Paddy and Water Environment. 11 (1), 381, 2013.

44. CHILUNDO M., JOEL A., WESSTROM I., BRITO R., MESSING I. Influence of irrigation and fertilisation management on the seasonal distribution of water and nitrogen in a semi-arid loamy sandy soil. Agricultural Water Management. 199, 120, 2018.

45. LIANG B., ZHAO W., YANG X., ZHOU J. Fate of nitrogen-15 as influenced by soil and nutrient management history in a 19-year wheat-maize experiment. Field Crops Research, 144, 126, 2013.

46. HOSSAIN M., WHITE S., ELAHI S., SULTANA N., CHOUDHURY M., ALAM Q., ROTHER J., GAUNT J. The efficiency of nitrogen fertiliser for rice in Bangladeshi farmers' fields. Field Crops Research, 93 (1), 94, 2005. 
